\title{
Preliminary Health Risk Assessment in Relation to Some Trace Elements in Ogunpa River, South-Western Nigeria
}

\author{
${ }^{1}$ Omotoso, O. A.; ${ }^{2}$ Ojo, O. J.; ${ }^{3}$ Ige, O. O.; ${ }^{4}$ Olaleye, I. M.; ${ }^{5}$ Adewoye, O. A. and ${ }^{6}$ Olelewe, M. C. \\ 1,2,3,4,5,6 Department of Geology and Mineral Sciences; University of Ilorin, Ilorin, Nigeria; \\ ${ }^{2}$ Department of Geology, Federal University Oye-Ekiti, Nigeria \\ ${ }^{5}$ Department of Earth Science; Ladoke Akintola University of Technology, Ogbomoso, Nigeria
}

Corresponding Author E-mail: Omotoso.oa@ unilorin.edu.ng

Tel:

08067780267

Submitted on: 02/10/2020;

Accepted on: 13/01/2021

\begin{abstract}
Ogunpa River receives municipal and industrial waste discharge from its catchments and these have depleted the quality of the water. Hence, this research examines the preliminary environmental impacts and health implications of some trace elements in the water using Inductively Coupled Plasma-Mass Spectrometry (ICP-MS) laboratory technique. Average values of $\mathrm{Al}, \mathrm{Ba}, \mathrm{Fe}, \mathrm{Mn}, \mathrm{Ni}$ and $\mathrm{Pb}$ are above the recommended limits of $\mathrm{WHO}$. The CF showed that the trace elements varied from considerable contamination factor to very high contamination factor and the degree of contamination varied from 1023 to 11640. The hazard quotient computed for the adults is generally less than unity except $\mathrm{Pb}$ that has average value of 1.27. In children, the computed hazard quotient on the average ranges from 0.000572 to 4.04. $\mathrm{Al}, \mathrm{As}, \mathrm{Ba}, \mathrm{Cr}, \mathrm{Cu}, \mathrm{Ni}, \mathrm{Zn}$ and $\mathrm{Cd}$ have their average values less than unity respectively, while $\mathrm{Fe}, \mathrm{Mn}$ and $\mathrm{Pb}$ has their average values greater than one. The Hazard Index (HI) in adults and children are greater than one. Carcinogenic risk assessment was computed for $\mathrm{Cr}, \mathrm{Pb}$ and $\mathrm{Cd}$ which was greater than $10^{-6}$ in children and adult. Only $\mathrm{Cd}$ in adult was less than the prescribed limit of $10^{-6}$. Effort should be made to checkmate indiscriminate dumping of refuse and sewages into the water body as these could serve as pollutants to other adjourning rivers and main water bodies. In conclusion, the water is not fit for domestic, agricultural and probably industrial uses because of its health implications on consumption.
\end{abstract}

Keywords: Ogunpa river, contamination factor, degree of contamination, Hazard quotient, hazard index, carcinogenic health risk

\section{Introduction}

Water is very essential for life, accounting for $70 \%$ of the human body. It is the basic essentials for human existence, survival and social development which is the indispensable materials for daily inventions and life. Safe and clean portable water is important to human health and also an important indicator to measure social development and human life quality (Chang, 2013; Li et al., 2019). In recent years, due to development of the industrialized society, the environment has been deteriorated leading to water pollution catastrophes. It has been discovered that majority of the drinking water sources (surface water) have brought great threats to human health. As a result of lack of proper disinfection and treatment facilities, people have poor drinking water. Rivers generally are liable to indiscriminate dumping of municipal wastes. Although some of these rivers may not be directly consumed by people but they serve as tributaries to other rivers and main water bodies that other people consume. The effects of pollution are somehow reflected in the quality of the main water bodies. The Health Risk Assessment (HRA) of water emerged in the inception of 1980s (Chang, 2013; Li et al., 2019). It adopted the concept of risk as an appraisal index to link environmental pollution with human health and quantitatively describing the risk of pollution to human health (Han, 2011; Li et al., 2019). Interestingly, several researches related to HRA has been conducted 
using the method prescribed by the USEPA around the world (Yuan et al, 2017; Li et al., 2019). Through the evaluation of the level of damage to human health, health risk assessment (HRA) can serve as a guide by administrative sector in water environment protection, pollution remediation and water environment risk management ((Khadam and Kaluarachchi, 2003; Kavcar et al. 2009; Li et al., 2019).

Ogunpa river is one of the main rivers at the center of Ibadan metropolis, south western Nigeria that receives effluents from various activities far and near within certain parts of Ibadan city. Consequently, this research surveys the environmental impacts and health implications of some selected trace elements in the river.

In general, Ibadan metropolis is situated South West of Nigeria. The study area lies between longitudes $7^{\circ} 21^{\prime} 15^{\prime} ' \mathrm{~N}$ and $7^{\circ} 21^{\prime} 50^{\prime} ' \mathrm{~N}$ and latitude $3^{\circ} 53^{\prime} 10^{\prime}{ }^{\prime} \mathrm{E}$ and $3^{\circ} 53^{\prime} 50^{\prime \prime} \mathrm{E}^{\prime}$. According to population census 1991, Ibadan has a population of 1,288,666 and slightly in excess of 1,338,659 in the year 2006 according to National Population Commission estimates. Ibadan is a commercial center and in recent times has witnessed an explosion in population, industrialization and an increased tempo of economic activities. The Geology of Ibadan and environs, including Ogunpa area, falls within the Pre-Cambrian rocks of Southwestern Nigeria. The main rock types are schistquartzites, granite-gneiss, banded gneiss, augen-gneiss, and migmatites (Jones and Hockey, 1964), while minor rock types like pegmatite, aplites, quartz veins and dolerite dykes intruded the main rocks in Ibadan metropolis. Oladunjoye et al (2013) reported that Gneisses are migmatized in places and are characterized by predominantly medium-sized grains while schist quartzites occur as elongated ridges striking NW-SE. Moreover, the study area is typified by banded and migmatite gneisses which generally strike NW-SE and dip to the east. It was further reported that the joints on the outcrops in the area are mostly oriented perpendicular to the strike (NW-SE) of the rock foliation. In addition, some notable N-S and NW-SE plunging minor folds were mapped on the gneiss complex. Figure 1 present the location map of the area of study.

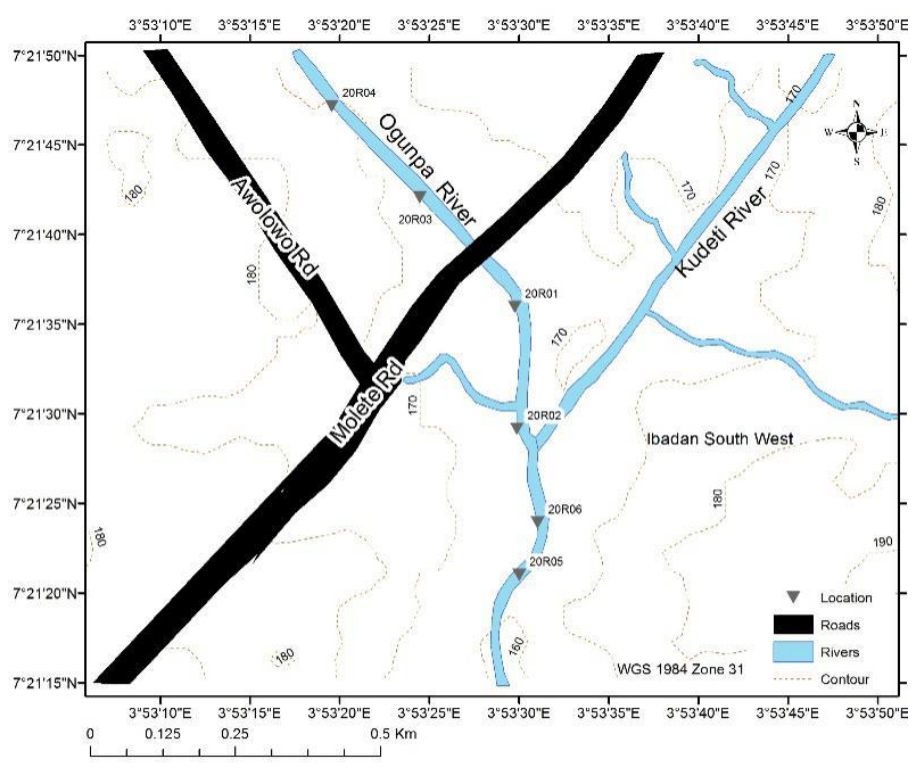

Figure. 1: Parts of Topographical Map of Ibadan, showing the Location of the study area and Sampling Points 
The sampling activities were carried out in January 2020. The study is just a preliminary study to further studies, hence, a total of six water samples were randomly sampled along the river channel with the aid of GPS. $60 \mathrm{ml}$ white plastic containers were used for the water sampling. The containers were rinsed severally by the water to be put in them and few drops of concentrated nitric acid were added to each of the water-filled bottles and corked immediately. The acid prevents the precipitations of the cations from solution. The samples were analyzed in ACME laboratory in Vancouver, Canada, North America. ICP-MS laboratory technique was used for the analysis of the cations. Only 11 trace elements were selected from the laboratory results for this study and the following were the selected trace elements: $\mathrm{Al}, \mathrm{As}, \mathrm{Ba}, \mathrm{Cr}, \mathrm{Cu}, \mathrm{Fe}, \mathrm{Mn}, \mathrm{Ni}, \mathrm{Pb}, \mathrm{Zn}$ and $\mathrm{Cd}$.

\section{Data Appraisal}

Table 1 presents the World Health Organization (WHO) standard for drinking water quality and the mean composition of world rivers respectively.

Table 1: World Health Organization (2006) and Nigerian Standards for Drinking Water Quality for Potable Water (2007) and Mean Composition of World Rivers (2009).

\begin{tabular}{cccc}
\hline Trace Elements & $\begin{array}{l}\text { WHO } \\
\text { Standard } \\
(\mathrm{ppm}), 2006\end{array}$ & $\begin{array}{l}\text { NSDWQ, } \\
\text { 2007 (ppm) }\end{array}$ & $\begin{array}{l}\text { Mean composition of world rivers in } \\
\text { ppm, (after Viers } \text { et al., 2009) }\end{array}$ \\
\hline Aluminum, Al & 0.2 & 0.2 & 0.32 \\
Arsenic, As & 0.01 & 0.01 & 0.00062 \\
Barium, $\mathrm{Ba}$ & 0.3 & 0.7 & 0.023 \\
Chromium, $\mathrm{Cr}$ & 0.05 & 0.05 & 0.0007 \\
Copper, $\mathrm{Cu}$ & 2 & 1 & 0.00148 \\
Iron, Fe & 0.3 & 0.3 & 0.066 \\
Manganese, & 0.5 & 0.2 & 0.00042 \\
Mn & & & 0.0008 \\
Nickel, $\mathrm{Ni}$ & 0.02 & 0.001 & 0.00008 \\
Lead, $\mathrm{Pb}$ & 3 & 0.01 & 0.0006 \\
Cadmium, Cd & 0.003 & 0.003 & \\
\hline
\end{tabular}

Contamination Factor: This is the single index usually determined by the following relation:

$$
C f=\frac{C m}{B m}
$$

$\mathrm{Cf}$ is the contamination factor of the trace element of interest; $\mathrm{Cm}$ is the concentration of the trace element in the sample; $\mathrm{Bm}$ is the background concentration of the trace element in the sample. According to Atiemo et al., 2011, there are four categories of contamination factors which include the following: $<1=$ low contamination factor; $1-3=$ moderate contamination factor; $3-6=$ considerable contamination factor; $>6=$ very high contamination factor. 
Degree of Contamination $\left(\mathbf{C}_{\mathbf{d e g}}\right)$ : This is the addition of all the contamination factors in the sample and it is expressed as:

$$
C_{d e g}=\sum^{c_{m}} /_{B_{m}}
$$

$\mathrm{C}_{\mathrm{m}}$ is the concentration of the element $\mathrm{m}$ in the water; $\mathrm{B}_{\mathrm{m}}$ is the local background concentration of trace element, $\mathrm{m}$ within the pristine area of catchment. Atiemo et al., 2011 also identified four categories namely: low degree of contamination $(<8)$; moderate degree of contamination $(8$ - 16); considerable degree of contamination (16 - 32); and very high degree of contamination (> 32).

The Average Daily Dose: The Average Daily Dose (ADD) was determined using equation 3 to estimate the health risk of the samples taken from Ogunpa River.

$$
A D D=\frac{C w a t e r * I R * E F * E D}{B W * A T}
$$

where, ADD is the average daily dose through ingestion of water $(\mu \mathrm{g} / \mathrm{kg} / \mathrm{day}) ; \mathrm{C}_{\text {water }}$ is the average concentration of the estimated metals in water $(\mu \mathrm{g} / \mathrm{L})$; IR is the ingestion rate in this research (2.2 L/day for adults; $1.8 \mathrm{~L} /$ day for children); EF is the exposure frequency (365 days/year); ED is the exposure duration (70 years for adults; and 6 years for children); BW is the average body weight (70 kg for adults; $15 \mathrm{~kg}$ for children); AT is the average time (365 days/year $\times 70$ years for an adult; 365 days/year $\times 6$ years for a child)- Edokpayi, et al. (2018).

Hazard Quotient (HQ): The non-carcinogenic risk as a result of the exposure to surface water resources consumption was computed as the hazard quotient (HQ). The formula below is used to calculate the HQ of the river water in Ogunpa, Ibadan:

$$
H Q=A D D / R_{f} D
$$

ADD is the average daily dose similar to the exposure dose through ingestion of water $(\mu \mathrm{g} / \mathrm{kg} / \mathrm{day})$; $\mathrm{R}_{\mathrm{f}} \mathrm{D}$ is the reference dose of specific element. The reference dose for $\mathrm{Al}, \mathrm{As}, \mathrm{Ba}, \mathrm{Cr}, \mathrm{Cu}, \mathrm{Fe}, \mathrm{Mn}$, $\mathrm{Ni}, \mathrm{Pb}$ and $\mathrm{Zn}$ are: $1,0.0003,0.2,1.5,0.04,0.7,0.046,0.02,0.0035$ and $0.3 \mathrm{mg} / \mathrm{kg} /$ day, respectively (USEPA, 2001). If the value of HQ is greater than unity, that is, 1, there is possibility of noncarcinogenic negative effects on health while HQ value less than 1 implies that the exposure to the surface water consumption would not likely have any effect on the consumers (USEPA 2001, Yuan et al., 2017; Maxwell et al., 2018; Joel et al., 2018).

Hazard Index (HI): To assess the overall potential non-carcinogenic effects posed by more than one metal and pathway, the addition of the computed HQs across metals was expressed as hazard index (HI) using equation 5 after USEPA (1989):

$$
H I=\sum_{i=1}^{n} H Q
$$

$\mathrm{HI}>1$ is an indication of a potential adverse effect on human health (Li SY and Zhang, 2010; Naveedullah et al., 2014).

Chronic Daily Intake (CDI): Edokpayi et al (2018) calculated Chronic Daily Intake (CDI) of trace elements through ingestion using equation 6 :

$$
C D I=C_{\text {water }} * \frac{D I}{B W}
$$


LAUTECH Journal of Civil and Environmental Studies

Volume 6, Issue 1; March 2021

Carcinogenic Risk (CR): Edokpayi et al (2018) also used the equation 7 to estimate the carcinogenic risk (CR) through ingestion and this was also adopted in this research:

$$
C R_{\text {ing }}={ }^{E x p_{\text {ing }} / S F_{\text {ing }}}
$$

where, $\mathrm{CR}_{\text {ing }}=$ carcinogenic risk via ingestion route and $\mathrm{SF}_{\text {ing }}=$ carcinogenic slope factor where $\mathrm{Pb}$ is $8.5 \mathrm{E}, \mathrm{Cd}$ is $6.1 \mathrm{E}+03$ and $\mathrm{Cr}$ is $5.0 \mathrm{E}+02 \mu \mathrm{g} / \mathrm{kg} /$ day (Iqbal and Shah, 2013; Naveedullah et al.,

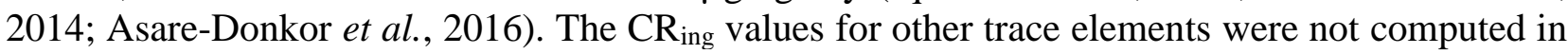
this study because of unavailability of the $\mathrm{SF}_{\text {ing }}$ values.

\section{Results and Discussion}

\section{Hydrochemical Analysis Results and Discussion}

The hydrochemical analysis results of selected trace elements and their respective descriptive statistical summary were presented in Table 2 . The profile of the concentrations of the selected trace elements and the profile of average concentrations of the selected trace elements were also presented in Figures 2 and 3 respectively.

Aluminum (Al): Al has a range between 0.23 and $3.49 \mathrm{ppm}$ (average=1.25ppm; standard deviation=1.56; median $=0.27 \mathrm{ppm}$ ). All the values of $\mathrm{Al}$ in the water are greater than $0.2 \mathrm{ppm}$ recommended by WHO (2006) and NSDWQ (2007). It has been reported that Al toxicity could results in neuro-degenerative disorders (NSDWQ, 2007). The elevated values of $\mathrm{Al}$ in the water is as a result of various anthropogenic activities around the study area (Motor mechanics activities, marketing, effluent from municipal waste disposals, leachate from households' materials and sewage disposals).

Arsenic (As): Arsenic ranges from 0.0015 to $0.0037 \mathrm{ppm}$ (average $=0.0024 \mathrm{ppm}$; standard deviation $=0.001$; median $=0.002 \mathrm{ppm}$ ). The value is lower than the recommended values of WHO, $2006(0.01 \mathrm{ppm})$ and NSDW, $2007(0.01 \mathrm{ppm})$. Since traces of Arsenic were observed, caution should be taken to prevent Arsenic toxicity in the water body because it can lead to various types of cancer infections when the water is ingested (NSDW, 2007). It has been reported that Arsenic enters the bodies of water via both natural and anthropogenic sources. Arsenic also is used in various agricultural insecticides, herbicides, animal diseases prevention and the stimulants for chickens as well as swine which could increase the concentration level in the water phase (Ekere et al., 2014).

Barium (Ba): The concentrations of Barium in the water body ranged from 0.1 to $1.29 \mathrm{ppm}$ with an average of $0.4 \mathrm{ppm}$ higher than the prescribed limit of 0.3ppm (WHO, 2006). Contributions from municipal waste disposal is more pronounced in the area leading to increase in the level of Ba. Barium causes hypertension in man. Hence, measures must be taken to stop indiscriminate dumping of refuse and channeling of sewage materials into the river channel.

Iron (Fe): The concentrations of Fe in the samples ranged from 1.23 to $17.78 \mathrm{ppm}$ with an average of 6.03ppm and median $1.37 \mathrm{ppm}$. Details could be seen in Table 2. It was observed that all the samples had elevated values of Fe greater than the recommendations of WHO and NSDWQ. It has been reported that excess iron in water and food constitutes health hazard to human being (Ekere et al., 2014). Chronic intake of water containing overloaded iron results in gene mutation leading to haemochromatosis whose symptoms include fatigue, weight loss, joint pains and ultimately heart disease, liver problems and diabetes (Ekere et al., 2014). It is suggested that the sources of the iron are chiefly from various anthropogenic activities in the study area and little contribution from the weathering of rock types in the area. 
Manganese (Mn): The concentrations of $\mathrm{Mn}$ in the water samples ranged from 0.32 to $1.58 \mathrm{ppm}$ with an average of $0.65 \mathrm{ppm}$. All the values are greater than $0.2 \mathrm{ppm}$ prescribed by NSDW, 2007. Based on the average, the value obtained (average $=0.65 \mathrm{ppm})$ is higher than the value $(0.5 \mathrm{ppm})$ recommended by WHO (2006). The high concentrations may be as a result of landfill leachate leaching/flowing into the river (Edokpayi et al., 2018). It has been reported that concentrations between 0.1 and $0.15 \mathrm{ppm}$ could cause critical stain and taste problems (DWAF, 1996; WHO, 2006; Edokpayi et al., 2018).

Table 2: Concentrations and Descriptive Statistical Summary of the Selected Trace Elements (in ppm) in Ogunpa River

\begin{tabular}{ccccccccccccc}
\hline $\begin{array}{c}\text { Sample } \\
\text { ID }\end{array}$ & Al & As & $\mathrm{Ba}$ & $\mathrm{Cr}$ & $\mathrm{Cu}$ & $\mathrm{Fe}$ & $\mathrm{Mn}$ & $\mathrm{Ni}$ & $\mathrm{Pb}$ & $\mathrm{Zn}$ & $\mathrm{Cd}$ \\
\hline $\begin{array}{c}\text { WHO, } \\
\text { 2006 }\end{array}$ & 0.2 & 0.01 & 0.3 & 0.05 & 2 & 0.3 & 0.5 & 0.02 & 0.01 & 3 & 0.003 \\
$\begin{array}{c}\text { NSDW, } \\
\text { 2007 }\end{array}$ & 0.2 & 0.01 & 0.7 & 0.05 & 1 & 0.3 & 0.2 & 0.001 & 0.01 & 3 & 0.003 \\
\hline 20 RO1 & 3.48700 & 0.00360 & 1.29437 & 0.01540 & 0.85680 & 13.17300 & 1.58296 & 0.01170 & 0.39610 & 1.19780 & 0.00279 \\
20 RO2 & 0.26700 & 0.00180 & 0.15152 & 0.00280 & 0.03620 & 1.22500 & 0.31627 & 0.00400 & 0.01110 & 0.04000 & 0.00016 \\
20 RO3 & 3.03300 & 0.00370 & 0.64252 & 0.01520 & 0.44970 & 17.77200 & 0.76989 & 0.01760 & 0.28120 & 0.67560 & 0.00419 \\
20 RO4 & 0.22700 & 0.00180 & 0.16277 & 0.00300 & 0.00890 & 1.46400 & 0.37182 & 0.00380 & 0.00710 & 0.02880 & 0.00010 \\
20 RO5 & 0.27400 & 0.00150 & 0.15329 & 0.00280 & 0.00630 & 1.24600 & 0.45887 & 0.00330 & 0.00330 & 0.01500 & 0.00006 \\
20 RO6 & 0.23100 & 0.00170 & 0.14969 & 0.00370 & 0.01020 & 1.28400 & 0.39476 & 0.00380 & 0.00740 & 0.06250 & 0.00009 \\
average & 1.25317 & 0.00235 & 0.42569 & 0.00715 & 0.22802 & 6.02733 & 0.64910 & 0.00737 & 0.11770 & 0.33662 & 0.00123 \\
min & 0.22700 & 0.00150 & 0.14969 & 0.00280 & 0.00630 & 1.22500 & 0.31627 & 0.00330 & 0.00330 & 0.01500 & 0.00006 \\
max & 3.48700 & 0.00370 & 1.29437 & 0.01540 & 0.85680 & 17.77200 & 1.58296 & 0.01760 & 0.39610 & 1.19780 & 0.00419 \\
stdev & 1.56121 & 0.00101 & 0.46825 & 0.00632 & 0.35381 & 7.45982 & 0.48481 & 0.00595 & 0.17498 & 0.49353 & 0.00180 \\
var & 2.43739 & 0.00000 & 0.21926 & 0.00004 & 0.12518 & 55.64890 & 0.23504 & 0.00004 & 0.03062 & 0.24357 & 0.00000 \\
med & 0.27050 & 0.00180 & 0.15803 & 0.00335 & 0.02320 & 1.37400 & 0.42682 & 0.00390 & 0.00925 & 0.05125 & 0.00013 \\
\hline
\end{tabular}

Lead (Pb): The concentrations recorded for Lead also ranged from 0.003 to $0.396 \mathrm{ppm}$ with an average of $0.12 \mathrm{ppm}$. Based on the average value computed, it is higher than the recommended values by WHO and NSDW $(0.01 \mathrm{ppm})$. It is reported that lead is stored in the skeleton with a halflife of 20 to 30 years (WHO, 1995; Edokpayi et al., 2018). The following are the acute symptoms of lead poisoning: headache, irritability, abdominal pains and symptoms related to nervous system (Ekere et al., 2014). Also, long term exposure in children may lead to diminished intellectual capability, encephalopathy, acute psychosis and reduces ability to understand (WHO, 1995; Ekere et al., 2014). Improper sewage and refuse disposal may result to leaching of $\mathrm{Pb}$ into the river thereby increasing the concentration.

Nickel (Ni): The concentrations of Ni ranged from 0.0033 to $0.018 \mathrm{ppm}$ (average $=0.007 \mathrm{ppm}$; median $=0.004 \mathrm{ppm}$ ). Based on the average, the concentration of Nickel is lower than 0.02ppm prescribed by WHO. However, concentrations are generally higher than the recommended values by NSDWQ. It is of interest to note that Nickel is necessary in many organism's diets. However, it can become carcinogenic and toxic in high doses. It has been observed that women are more commonly allergic to nickel exposure than men. Exposure to skin can cause dermatitis upon contact. The source could be from the electroplating waste discharge into the river bodies without treatment. 
LAUTECH Journal of Civil and Environmental Studies

Volume 6, Issue 1; March 2021

Chromium (Cr), Copper (Cu), Zinc (Zn) and Cadmium (Cd): The average concentrations of $\mathrm{Cr}$, $\mathrm{Cu}, \mathrm{Zn}$ and $\mathrm{Cd}$ are 0.0072, 0.23, 0.34 and $0.0012 \mathrm{ppm}$ respectively. Detailed statistical summary is presented in Table 2. The values are generally below the recommended values of WHO and NSDWQ.

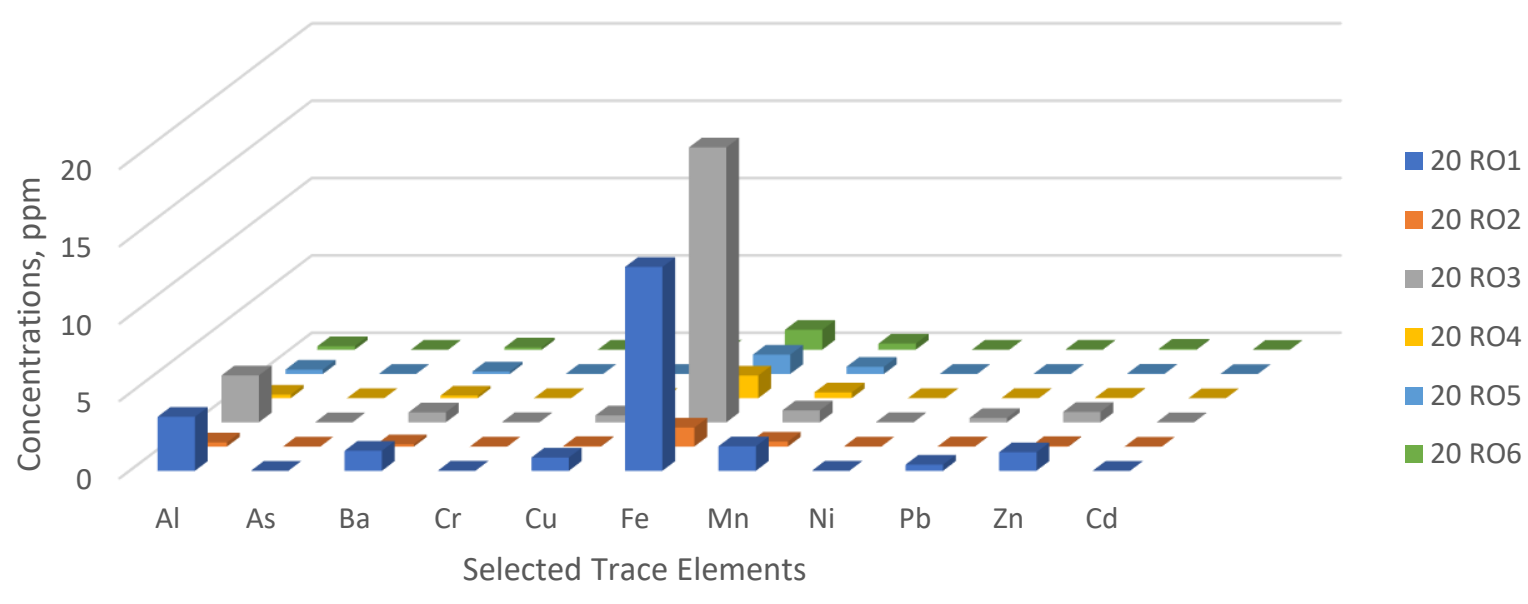

Figure 2: Profile of the Concentrations of the Selected trace Elements

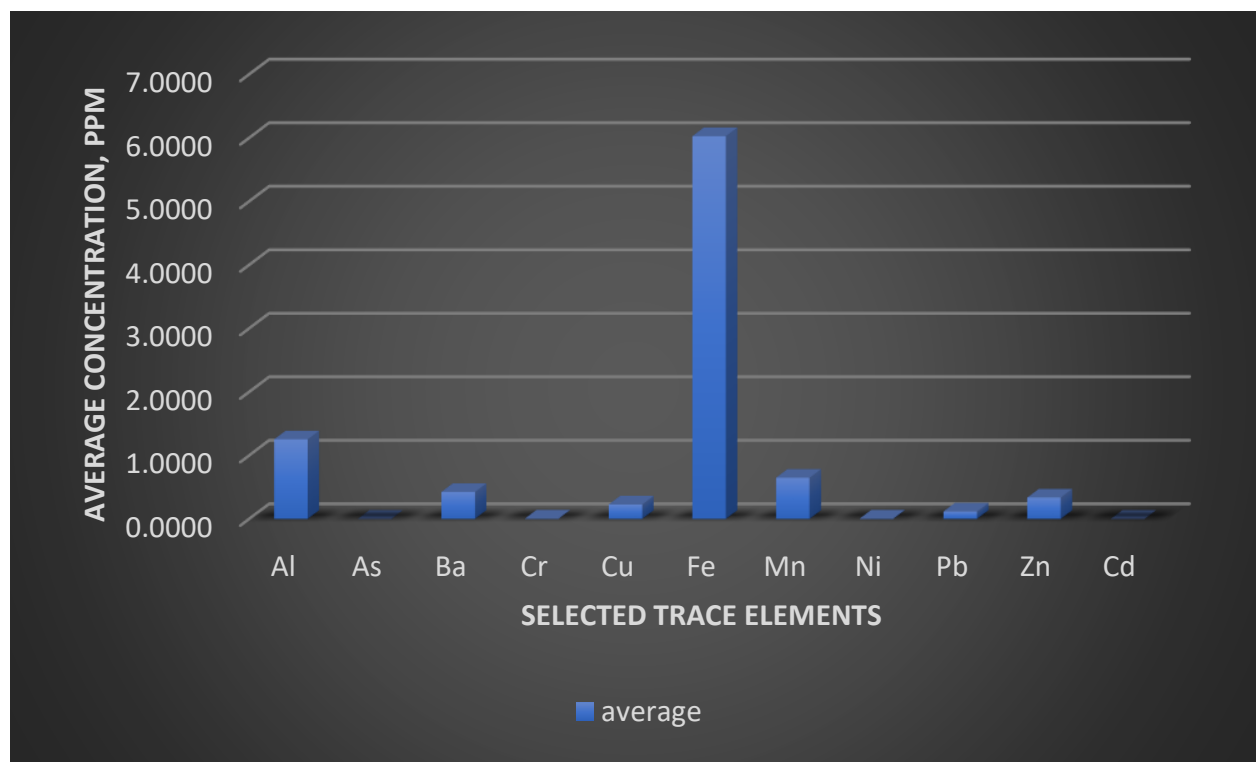

Figure 3: Profile of Average Concentrations of the Selected Trace Elements 


\section{Assessment of Contamination}

Assessment of contamination of the water was carried out by computing the contamination factor and degree of contamination of the trace elements in the water samples.

Contamination Factor (CF) and Degree of Contamination ( $\left.\mathbf{D}_{\mathbf{d e g}}\right)$ : Table 3 presents the computed contamination factors and degree of contamination of the trace elements in the samples. The average contamination factors of $\mathrm{Al}, \mathrm{As}, \mathrm{Ba}, \mathrm{Cr}, \mathrm{Cu}, \mathrm{Fe}, \mathrm{Mn}, \mathrm{Ni}, \mathrm{Pb}, \mathrm{Zn}$ and $\mathrm{Cd}$ are: 3.92, 3.79, 18.51, $10.21,154.07,91.32,1545.46,9.21,1471.25,561.03$ and 15.4 respectively. The $\mathrm{CF}<1$ is an indication that the sources of elements are generally from natural activities (weathering of rock types in the area) while $\mathrm{CF}>1$ indicates sources from artificial or anthropogenic activities in the area of study (Tijani, 2007). The computed CF denotes contributions from various anthropogenic activities in the study area. The computed degree of contamination ranged from 1023 to 11640 , indicating very high degree of contamination of these elements in the samples. Figure 4 presents the profile of the degree of contamination in the water samples.

Table 3: Computed Statistical Description Summary of Contamination Indexes

\begin{tabular}{|c|c|c|c|c|c|c|c|c|c|c|c|}
\hline \multicolumn{12}{|c|}{ Contamination Factor, $\mathrm{CF}$} \\
\hline & $\mathrm{Al}$ & As & $\mathrm{Ba}$ & $\mathrm{Cr}$ & $\mathrm{Cu}$ & $\mathrm{Fe}$ & $\mathrm{Mn}$ & $\mathrm{Ni}$ & $\mathrm{Pb}$ & $\mathrm{Zn}$ & $\mathrm{Cd}$ \\
\hline $20 \mathrm{RO} 1$ & 10.90 & 5.81 & 56.28 & 22.00 & 578.92 & 199.59 & 3768.95 & 14.63 & 4951.25 & 1996.33 & 34.88 \\
\hline $20 \mathrm{RO} 2$ & 0.83 & 2.90 & 6.59 & 4.00 & 24.46 & 18.56 & 753.02 & 5.00 & 138.75 & 66.67 & 2.00 \\
\hline $20 \mathrm{RO} 3$ & 9.48 & 5.97 & 27.94 & 21.71 & 303.85 & 269.27 & 1833.07 & 22.00 & 3515.00 & 1126.00 & 52.38 \\
\hline $20 \mathrm{RO} 4$ & 0.71 & 2.90 & 7.08 & 4.29 & 6.01 & 22.18 & 885.29 & 4.75 & 88.75 & 48.00 & 1.25 \\
\hline 20 RO5 & 0.86 & 2.42 & 6.66 & 4.00 & 4.26 & 18.88 & 1092.55 & 4.13 & 41.25 & 25.00 & 0.75 \\
\hline 20 RO6 & 0.72 & 2.74 & 6.51 & 5.29 & 6.89 & 19.45 & 939.90 & 4.75 & 92.50 & 104.17 & 1.13 \\
\hline average & 3.92 & 3.79 & 18.51 & 10.21 & 154.07 & 91.32 & 1545.46 & 9.21 & 1471.25 & 561.03 & 15.40 \\
\hline $\min$ & 0.71 & 2.42 & 6.51 & 4.00 & 4.26 & 18.56 & 753.02 & 4.13 & 41.25 & 25.00 & 0.75 \\
\hline $\max$ & 10.90 & 5.97 & 56.28 & 22.00 & 578.92 & 269.27 & 3768.95 & 22.00 & 4951.25 & 1996.33 & 52.38 \\
\hline stdev & 4.88 & 1.63 & 20.36 & 9.03 & 239.06 & 113.03 & 1154.32 & 7.43 & 2187.24 & 822.55 & 22.56 \\
\hline var & 23.80 & 2.67 & 414.48 & 81.57 & 57151.22 & 12775.23 & 1332450.14 & 55.25 & 4784005.63 & 676586.78 & 508.92 \\
\hline med & 0.85 & 2.90 & 6.87 & 4.79 & 15.68 & 20.82 & 1016.23 & 4.88 & 115.63 & 85.42 & 1.63 \\
\hline
\end{tabular}




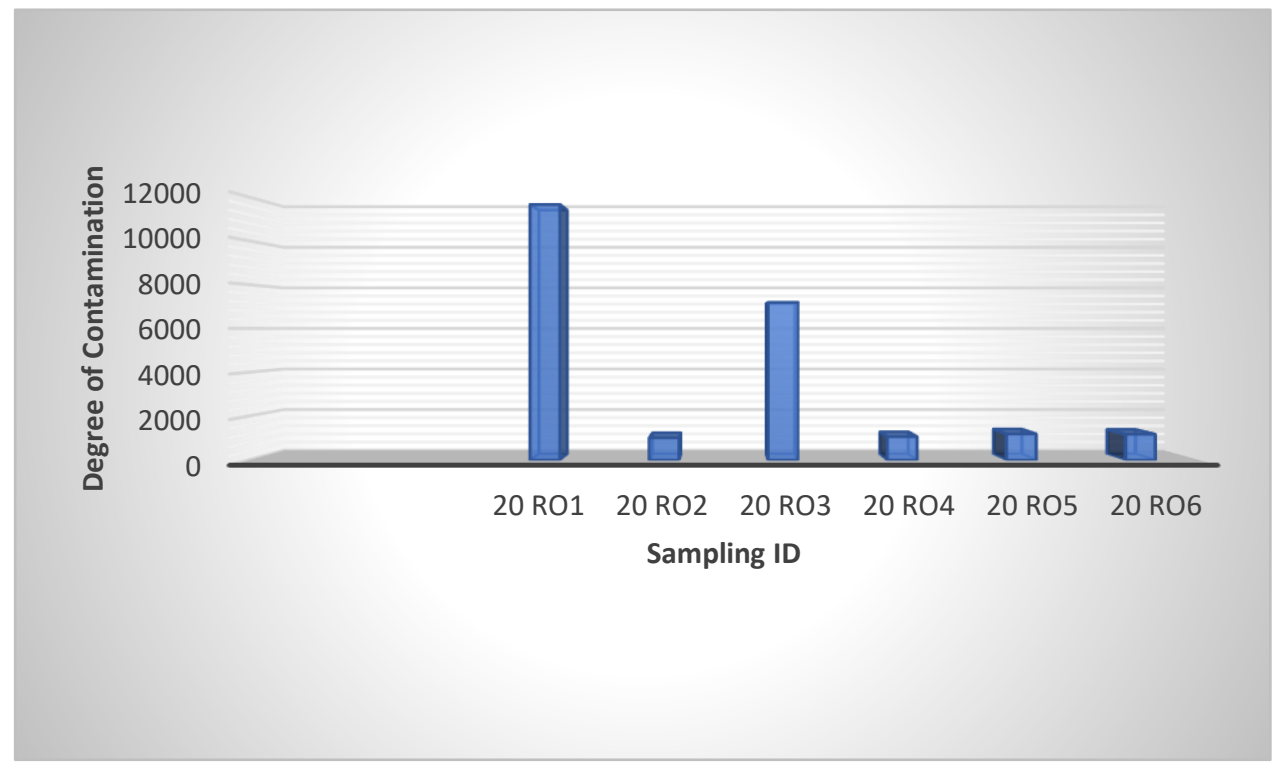

Figure 4: Profile of the Degree of Contamination in Ogunpa River

\section{Health Risk Assessment:}

The computed health risk assessment parameters are presented in Tables 4 and 5. The health risk assessment model introduced by the USEPA were adopted in this research to evaluate the health risks that trace elements could pose on human via direct ingestion of the water in Ogunpariver. The health-related risk associated with the exposure through ingestion is a factor of the weight, age and volume of water consumed by an individual which was determined using the measured minimum and maximum concentration of $\mathrm{Al}, \mathrm{As}, \mathrm{Ba}, \mathrm{Cr}, \mathrm{Cu}, \mathrm{Fe}, \mathrm{Mn}, \mathrm{Ni}, \mathrm{Pb}, \mathrm{Zn}$ and $\mathrm{Cd}$.

The Average Daily Intake: The average daily intake for adults and children is presented in Tables 4 and 5. The average values computed for $\mathrm{Al}, \mathrm{As}, \mathrm{Ba}, \mathrm{Cr}, \mathrm{Cu}, \mathrm{Fe}, \mathrm{Mn}, \mathrm{Ni}, \mathrm{Pb}, \mathrm{Zn}$ and $\mathrm{Cd}$ are 47.34, $0.089,16.08,0.27,8.61,227.7,24.52,0.28,4.45,12.72$ and $0.047 \mu \mathrm{g} \mathrm{kg}^{-1} \mathrm{day}^{-1}$ respectively. The average values computed for $\mathrm{As}, \mathrm{Cr}, \mathrm{Ni}$ and $\mathrm{Cd}$ are $<1$ while others are $>1$. The average values of trace elements computed for $\mathrm{Al}, \mathrm{As}, \mathrm{Ba}, \mathrm{Cr}, \mathrm{Cu}, \mathrm{Fe}, \mathrm{Mn}, \mathrm{Ni}, \mathrm{Pb}, \mathrm{Zn}$ and $\mathrm{Cd}$ in children are: 150.38, $0.282,51.083,0.858,27.36,732.28,77.89,0.88,14.12,40.39$ and $0.148 \mu \mathrm{g} \mathrm{kg}^{-1} \mathrm{day}^{-1}$ respectively. The average values computed for $\mathrm{As}, \mathrm{Cr}, \mathrm{Ni}$ and $\mathrm{Cd}$ are also $<1$ while others are $>1$. Therefore, similar trend is observed in both adults and children. The average daily intake greater than unity is an indication of potential negative health hazard on people that consume the polluted water. 
Table 4: Descriptive Average Daily Dose $\left(\mu \mathrm{g} \mathrm{kg}^{-1} \mathrm{day}^{-1}\right)$ of Ogunpa Water for Adults

\begin{tabular}{|c|c|c|c|c|c|c|c|c|c|c|c|}
\hline \multirow{2}{*}{$\begin{array}{l}\text { Sample } \\
\text { ID }\end{array}$} & \multicolumn{10}{|c|}{ Exposure Dose through Ingestion in Adults (Exping) } & \multirow[b]{2}{*}{$\mathrm{Cd}$} \\
\hline & $\mathrm{Al}$ & As & $\mathrm{Ba}$ & $\mathrm{Cr}$ & $\mathrm{Cu}$ & $\mathrm{Fe}$ & $\mathrm{Mn}$ & $\mathrm{Ni}$ & $\mathrm{Pb}$ & $\mathrm{Zn}$ & \\
\hline $20 \mathrm{RO} 1$ & 131.731 & 0.136 & 48.898 & 0.582 & 32.368 & 497.647 & 59.801 & 0.442 & 14.964 & 45.250 & 0.105 \\
\hline $20 \mathrm{RO} 2$ & 10.087 & 0.068 & 5.724 & 0.106 & 1.368 & 46.278 & 11.948 & 0.151 & 0.419 & 1.511 & 0.006 \\
\hline $20 \mathrm{RO} 3$ & 114.580 & 0.140 & 24.273 & 0.574 & 16.989 & 671.387 & 29.085 & 0.665 & 10.623 & 25.523 & 0.158 \\
\hline $20 \mathrm{RO} 4$ & 8.576 & 0.068 & 6.149 & 0.113 & 0.336 & 55.307 & 14.047 & 0.144 & 0.268 & 1.088 & 0.004 \\
\hline 20 RO5 & 10.351 & 0.057 & 5.791 & 0.106 & 0.238 & 47.071 & 17.335 & 0.125 & 0.125 & 0.567 & 0.002 \\
\hline $20 \mathrm{RO} 6$ & 8.727 & 0.064 & 5.655 & 0.140 & 0.385 & 48.507 & 14.913 & 0.144 & 0.280 & 2.361 & 0.003 \\
\hline average & 47.342 & 0.089 & 16.082 & 0.270 & 8.614 & 227.699 & 24.521 & 0.278 & 4.446 & 12.717 & 0.047 \\
\hline $\min$ & 8.576 & 0.057 & 5.655 & 0.106 & 0.238 & 46.278 & 11.948 & 0.125 & 0.125 & 0.567 & 0.002 \\
\hline $\max$ & 131.731 & 0.140 & 48.898 & 0.582 & 32.368 & 671.387 & 59.801 & 0.665 & 14.964 & 45.250 & 0.158 \\
\hline stdev & $\begin{array}{c}58.979 \\
3478.54\end{array}$ & 0.038 & 17.689 & 0.239 & 13.366 & 281.815 & 18.315 & 0.225 & 6.610 & 18.644 & 0.068 \\
\hline var & 8 & 0.0015 & 312.918 & 0.057 & 178.658 & 79419.918 & 335.446 & 0.050 & 43.696 & 347.615 & 0.005 \\
\hline med & 10.219 & 0.068 & 5.970 & 0.127 & 0.876 & 51.907 & 16.124 & 0.147 & 0.349 & 1.936 & 0.005 \\
\hline
\end{tabular}

Table 5: Descriptive Average Daily Dose $\left(\left(\mu \mathrm{g} \mathrm{kg}^{-1} \mathrm{day}^{-1}\right)\right.$ of Ogunpa Water for Children

\begin{tabular}{lcccccccccccccc}
\hline \multicolumn{10}{c}{ Exposure Dose through Ingestion in Children (Exping) } \\
\hline Sample ID & $\mathrm{Al}$ & $\mathrm{As}$ & $\mathrm{Ba}$ & $\mathrm{Cr}$ & $\mathrm{Cu}$ & $\mathrm{Fe}$ & $\mathrm{Mn}$ & $\mathrm{Ni}$ & $\mathrm{Pb}$ & $\mathrm{Zn}$ & $\mathrm{Cd}$ \\
\hline 20 RO1 & 418.440 & 0.432 & 155.324 & 1.848 & 102.816 & 1580.760 & 189.955 & 1.404 & 47.532 & 143.736 & 0.335 \\
20 RO2 & 32.040 & 0.216 & 18.182 & 0.336 & 4.344 & 147.000 & 37.952 & 0.480 & 1.332 & 4.800 & 0.019 \\
20 RO3 & 363.960 & 0.444 & 77.102 & 1.824 & 53.964 & 2132.640 & 92.387 & 2.112 & 33.744 & 81.072 & 0.503 \\
20 RO4 & 27.240 & 0.216 & 19.532 & 0.360 & 1.068 & 175.680 & 44.618 & 0.456 & 0.852 & 3.456 & 0.012 \\
20 RO5 & 32.880 & 0.180 & 18.395 & 0.336 & 0.756 & 149.520 & 55.064 & 0.396 & 0.396 & 1.800 & 0.007 \\
20 RO6 & 27.720 & 0.204 & 17.963 & 0.444 & 1.224 & 154.080 & 47.371 & 0.456 & 0.888 & 7.500 & 0.011 \\
\hline \multirow{2}{*}{ average } & 150.380 & 0.282 & 51.083 & 0.858 & 27.362 & 723.280 & 77.891 & 0.884 & 14.124 & 40.394 & 0.148 \\
\hline min & 27.240 & 0.180 & 17.963 & 0.336 & 0.756 & 147.000 & 37.952 & 0.396 & 0.396 & 1.800 & 0.007 \\
max & 418.440 & 0.444 & 155.324 & 1.848 & 102.816 & 2132.640 & 189.955 & 2.112 & 47.532 & 143.736 & 0.503 \\
stdev & 187.346 & 0.122 & 56.190 & 0.759 & 42.458 & 895.178 & 58.178 & 0.714 & 20.997 & 59.224 & 0.217 \\
var & 35098.424 & 0.015 & 3157.327 & 0.576 & 1802.650 & 801344.227 & 3384.637 & 0.509 & 440.894 & 3507.426 & 0.047 \\
med & 32.460 & 0.216 & 18.964 & 0.402 & 2.784 & 164.880 & 51.218 & 0.468 & 1.110 & 6.150 & 0.016 \\
\hline
\end{tabular}

Hazard Quotient (HQ) and Hazard Index (HI): The hazard quotient and hazard index computed for both adults and children are presented in Tables 6 and 7. For the adults, the average values computed is generally lower than unity except for $\mathrm{Pb}$ that has average value of 1.27. However, $\mathrm{Mn}$ in sample 20RO1 has a value of 1.3 above prescribed limit of 1. These indicate hazard effect of the water on the consumers. The order of abundance of the $\mathrm{HQ}$ for adults is: $\mathrm{Pb}>\mathrm{Mn}>\mathrm{Fe}>\mathrm{Cu}>\mathrm{Ba}>\mathrm{Al}$ $>\mathrm{Cd}>\mathrm{Zn}>\mathrm{Ni}>\mathrm{As}>\mathrm{Cr}$. The hazard index for adults ranges from 0.52 to 7.65 with an average of 2.53 above prescribed limit of one. This is an indication that the water has a high-risk health hazard to consumers. The profiles of hazard Index for adults and children are presented in Figures 5 and 6.

In children, the computed hazard quotient on the average ranges from 0.000572 in $\mathrm{Cr}$ to 4.04 in $\mathrm{Pb}$. $\mathrm{Al}, \mathrm{As}, \mathrm{Ba}, \mathrm{Cr}, \mathrm{Cu}, \mathrm{Ni}, \mathrm{Zn}$ and $\mathrm{Cd}$ have their average values less than one respectively, while $\mathrm{Fe}$, $\mathrm{Mn}$ and $\mathrm{Pb}$ have their average values $>1$ respectively. This is an indication of negative health risk 


\section{LAUTECH Journal of Civil and Environmental Studies \\ Volume 6, Issue 1; March 2021}

in the water of the study area. It has been suggested that estimated HQ values for trace elements more than unity for children should not be overlooked because children are very much susceptible to pollutants (Olujimi, et al., 2015; Giandomenico, et al., 2016; Sudsandee et al., 2017; Edokpayi, et al., 2018).

Table 6: Descriptive Statistics of Hazard Quotient and Hazard Index in the Adults

\begin{tabular}{|c|c|c|c|c|c|c|c|c|c|c|c|c|c|}
\hline & \multicolumn{11}{|c|}{ Hazard Quotient (Adults) } & \multicolumn{2}{|c|}{ Hazard Index } \\
\hline & $\mathrm{Al}$ & As & $\mathrm{Ba}$ & $\mathrm{Cr}$ & $\mathrm{Cu}$ & $\mathrm{Fe}$ & $\mathrm{Mn}$ & $\mathrm{Ni}$ & $\mathrm{Pb}$ & $\mathrm{Zn}$ & $\mathrm{Cd}$ & & \\
\hline $20 \mathrm{RO} 1$ & 0.1317 & 0.0097 & 0.2445 & 0.0004 & 0.8092 & 0.7109 & 1.3000 & 0.0221 & 4.2754 & 0.1508 & 0.1054 & $20 \mathrm{RO} 1$ & 7.65 \\
\hline $20 \mathrm{RO} 2$ & 0.0101 & 0.0049 & 0.0286 & 0.0001 & 0.0342 & 0.0661 & 0.2597 & 0.0076 & 0.1198 & 0.0050 & 0.0060 & $20 \mathrm{RO} 2$ & 0.54 \\
\hline $20 \mathrm{RO} 3$ & 0.1146 & 0.0100 & 0.1214 & 0.0004 & 0.4247 & 0.9591 & 0.6323 & 0.0332 & 3.0352 & 0.0851 & 0.1583 & $20 \mathrm{RO} 3$ & 5.42 \\
\hline $20 \mathrm{RO} 4$ & 0.0086 & 0.0049 & 0.0307 & 0.0001 & 0.0084 & 0.0790 & 0.3054 & 0.0072 & 0.0766 & 0.0036 & 0.0038 & $20 \mathrm{RO} 4$ & 0.52 \\
\hline 20 RO5 & 0.0104 & 0.0040 & 0.0290 & 0.0001 & 0.0060 & 0.0672 & 0.3768 & 0.0062 & 0.0356 & 0.0019 & 0.0023 & 20 RO5 & 0.54 \\
\hline 20 RO6 & 0.0087 & 0.0046 & 0.0283 & 0.0001 & 0.0096 & 0.0693 & 0.3242 & 0.0072 & 0.0799 & 0.0079 & 0.0034 & 20 RO6 & 0.54 \\
\hline average & 0.0473 & 0.0063 & 0.0804 & 0.0002 & 0.2153 & 0.3253 & 0.5331 & 0.0139 & 1.2704 & 0.0424 & 0.0465 & average & 2.53 \\
\hline $\min$ & 0.0086 & 0.0040 & 0.0283 & 0.0001 & 0.0060 & 0.0661 & 0.2597 & 0.0062 & 0.0356 & 0.0019 & 0.0023 & $\min$ & 0.52 \\
\hline $\max$ & 0.1317 & 0.0100 & 0.2445 & 0.0004 & 0.8092 & 0.9591 & 1.3000 & 0.0332 & 4.2754 & 0.1508 & 0.1583 & $\max$ & 7.65 \\
\hline stdev & 0.0590 & 0.0027 & 0.0884 & 0.0002 & 0.3342 & 0.4026 & 0.3982 & 0.0112 & 1.8887 & 0.0621 & 0.0682 & stdev & 3.18 \\
\hline var & 0.0035 & 0.0000 & 0.0078 & 0.0000 & 0.1117 & 0.1621 & 0.1585 & 0.0001 & 3.5670 & 0.0039 & 0.0046 & var & 10.1 \\
\hline med & 0.0102 & 0.0049 & 0.0299 & 0.0001 & 0.0219 & 0.0742 & 0.3505 & 0.0074 & 0.0998 & 0.0065 & 0.0049 & med & 0.54 \\
\hline
\end{tabular}

Table 7: Descriptive Statistics of Hazard Quotient and Hazard Index in Children

\begin{tabular}{lcccccccccccccc}
\hline \multicolumn{1}{c}{} & \multicolumn{1}{c}{ Hazard Quotient (HQ) in Children } \\
\hline & $\mathrm{Al}$ & $\mathrm{As}$ & $\mathrm{Ba}$ & $\mathrm{Cr}$ & $\mathrm{Cu}$ & $\mathrm{Fe}$ & $\mathrm{Mn}$ & $\mathrm{Ni}$ & $\mathrm{Pb}$ & $\mathrm{Zn}$ & $\mathrm{Cd}$ & \multicolumn{1}{c}{ HI, children } \\
\hline \hline 20 RO1 & 0.418 & 0.031 & 0.777 & 0.001 & 2.570 & 2.258 & 4.130 & 0.070 & 13.581 & 0.479 & 0.335 & $20 \mathrm{RO}$ & 24.65 \\
20 RO2 & 0.032 & 0.015 & 0.091 & 0.000 & 0.109 & 0.210 & 0.825 & 0.024 & 0.381 & 0.016 & 0.019 & $20 \mathrm{RO} 2$ & 1.72 \\
20 RO3 & 0.364 & 0.032 & 0.386 & 0.001 & 1.349 & 3.047 & 2.008 & 0.106 & 9.641 & 0.270 & 0.503 & $20 \mathrm{RO}$ & 17.71 \\
20 RO4 & 0.027 & 0.015 & 0.098 & 0.000 & 0.027 & 0.251 & 0.970 & 0.023 & 0.243 & 0.012 & 0.012 & $20 \mathrm{RO}$ & 1.68 \\
20 RO5 & 0.033 & 0.013 & 0.092 & 0.000 & 0.019 & 0.214 & 1.197 & 0.020 & 0.113 & 0.006 & 0.007 & 20 RO5 & 1.71 \\
20 RO6 & 0.028 & 0.015 & 0.090 & 0.000 & 0.031 & 0.220 & 1.030 & 0.023 & 0.254 & 0.025 & 0.011 & 20 RO6 & 1.73 \\
\hline average & 0.150 & 0.020 & 0.255 & 0.001 & 0.684 & 1.033 & 1.693 & 0.044 & 4.035 & 0.135 & 0.148 & average & 8.199185 \\
\hline \hline min & 0.027 & 0.013 & 0.090 & 0.000 & 0.019 & 0.210 & 0.825 & 0.020 & 0.113 & 0.006 & 0.007 & min & 1.68 \\
max & 0.418 & 0.032 & 0.777 & 0.001 & 2.570 & 3.047 & 4.130 & 0.106 & 13.581 & 0.479 & 0.503 & max & 24.65 \\
stdev & 0.187 & 0.009 & 0.281 & 0.001 & 1.061 & 1.279 & 1.265 & 0.036 & 5.999 & 0.197 & 0.217 & stdev & 10.29 \\
var & 0.035 & 0.000 & 0.079 & 0.000 & 1.127 & 1.635 & 1.600 & 0.001 & 35.991 & 0.039 & 0.047 & var & 105.89 \\
med & 0.033 & 0.015 & 0.095 & 0.000 & 0.070 & 0.236 & 1.113 & 0.023 & 0.317 & 0.021 & 0.016 & med & 1.72 \\
\hline \hline
\end{tabular}

The main contributors for non-carcinogenic health risk in this study area for children is Fe, Mn and $\mathrm{Pb}$. The computed cumulative $\mathrm{HI}$ across the trace elements served as a conservative assessment tool to estimate high-end risk rather than low-end risk in order to shield the public from possible health risk (Edokpayi, et al., 2018). The hazard index for children ranges from 1.68 to 24.65 with an average of 8.2. Based on these values computed for HI it is observed that exposure to these trace elements could pose adverse health risk to children. 


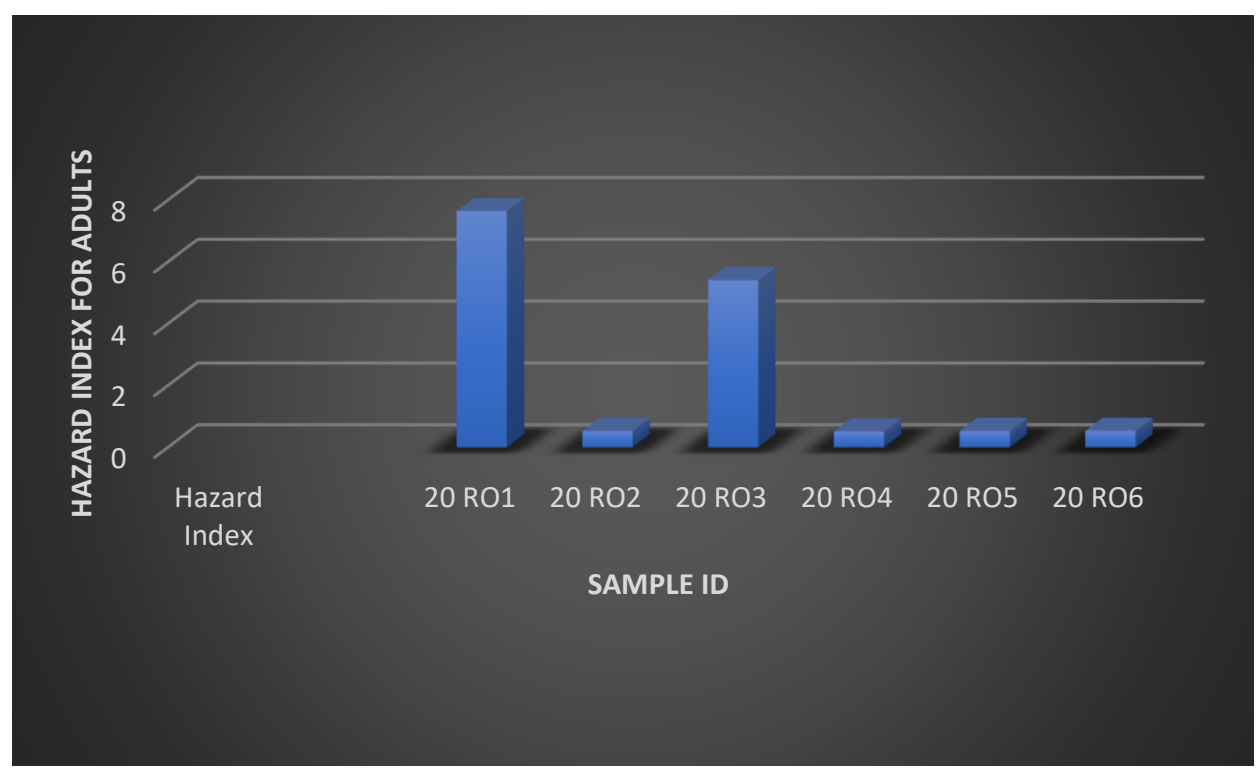

Figure 5: Profile of Hazard Index for Adults

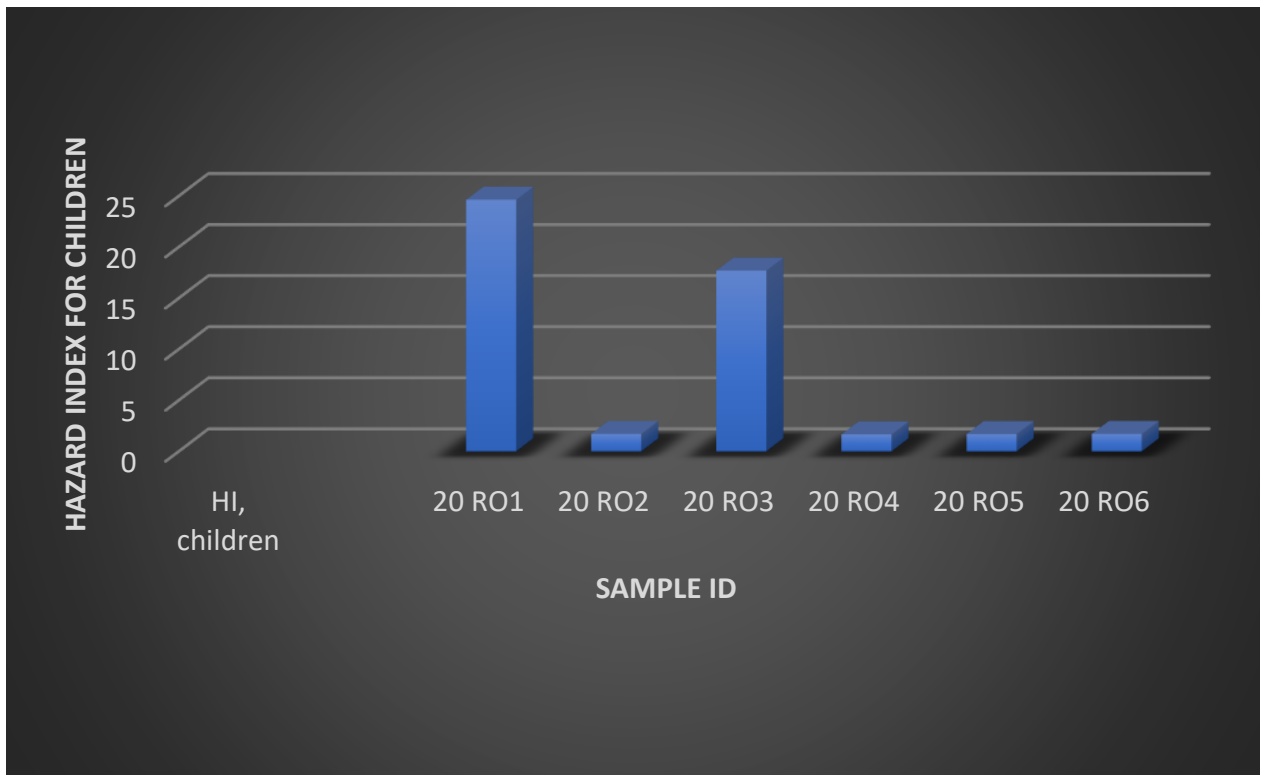

Figure 6: Profile of Hazard Index for Children

Chronic Daily Intake of Trace Elements (CDI): The average CDI values computed for Al, As, $\mathrm{Ba}, \mathrm{Cr}, \mathrm{Cu}, \mathrm{Fe}, \mathrm{Mn}, \mathrm{Ni}, \mathrm{Pb}, \mathrm{Zn}$ and $\mathrm{Cd}$ in adults are: 0.039, 7.39E-05, 0.0134, 2.2E-04, 0.0072, $0.189,0.02,2.3 \mathrm{E}-04,3.7 \mathrm{E}-03,0.01$ and $3.87 \mathrm{E}-05$ respectively while that of the children are: 0.15 , $0.00028,0.051,0.000858,0.027,0.723,0.077,0.000884,0.014,0.04$ and 0.000148 respectively (Tables 8 and 9). The following is the order of abundance of the average CDI for adults and children: $\mathrm{Fe}>\mathrm{Al}>\mathrm{Mn}>\mathrm{Ba}>\mathrm{Zn}>\mathrm{Cu}>\mathrm{Pb}>\mathrm{Ni}>\mathrm{Cu}>\mathrm{As}>\mathrm{Cd}$ respectively. Although, most of the computed values are less than one which show no evidence of non-carcinogenic hazard risk, there are evidence of hazard in values computed for Fe in samples 20R01 (1.58) and 20R03 (2.13). Figures 7 and 8 show CDI profiles for adults and children, respectively. 


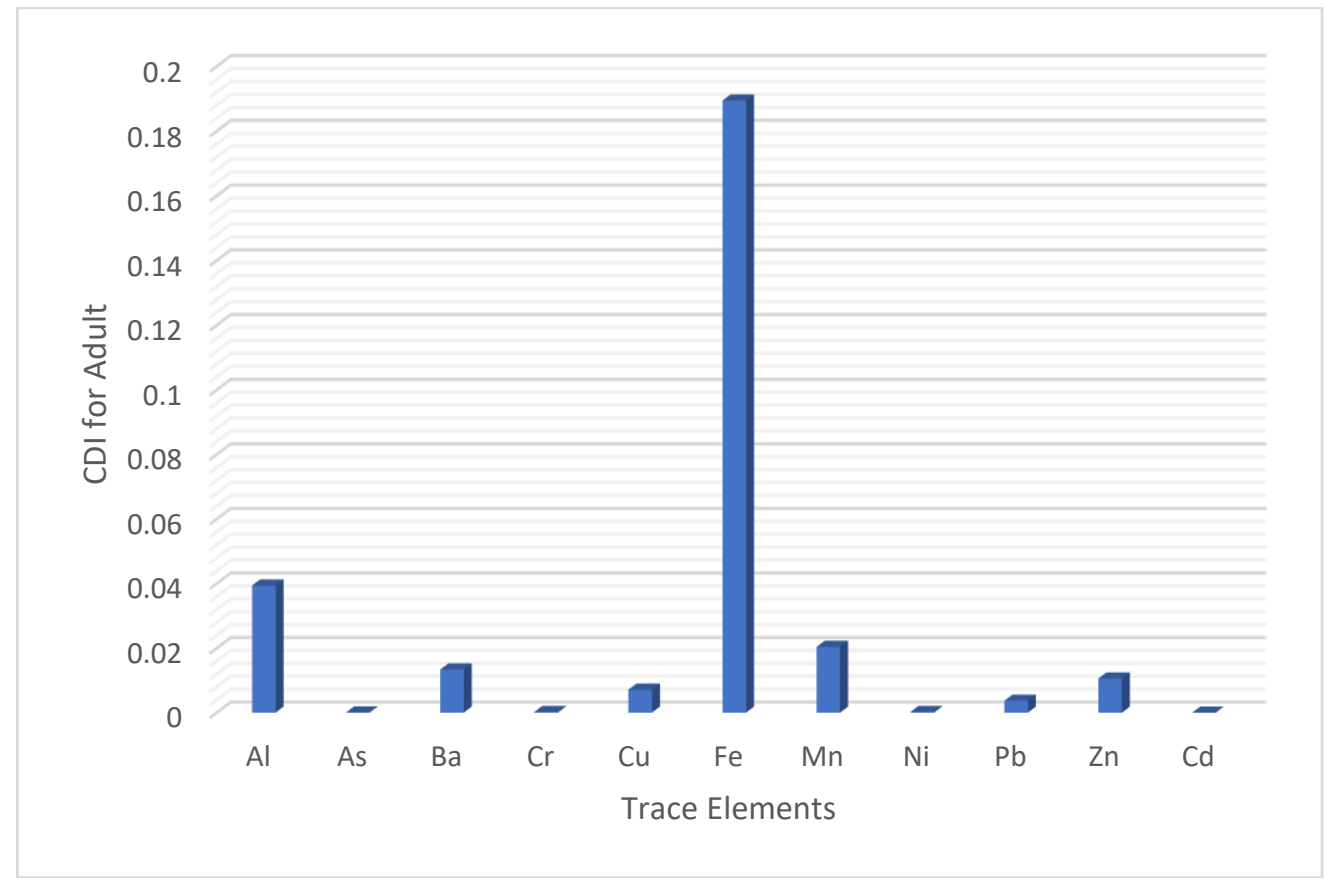

Figure 7: Profile of CDI Average Values for Adults

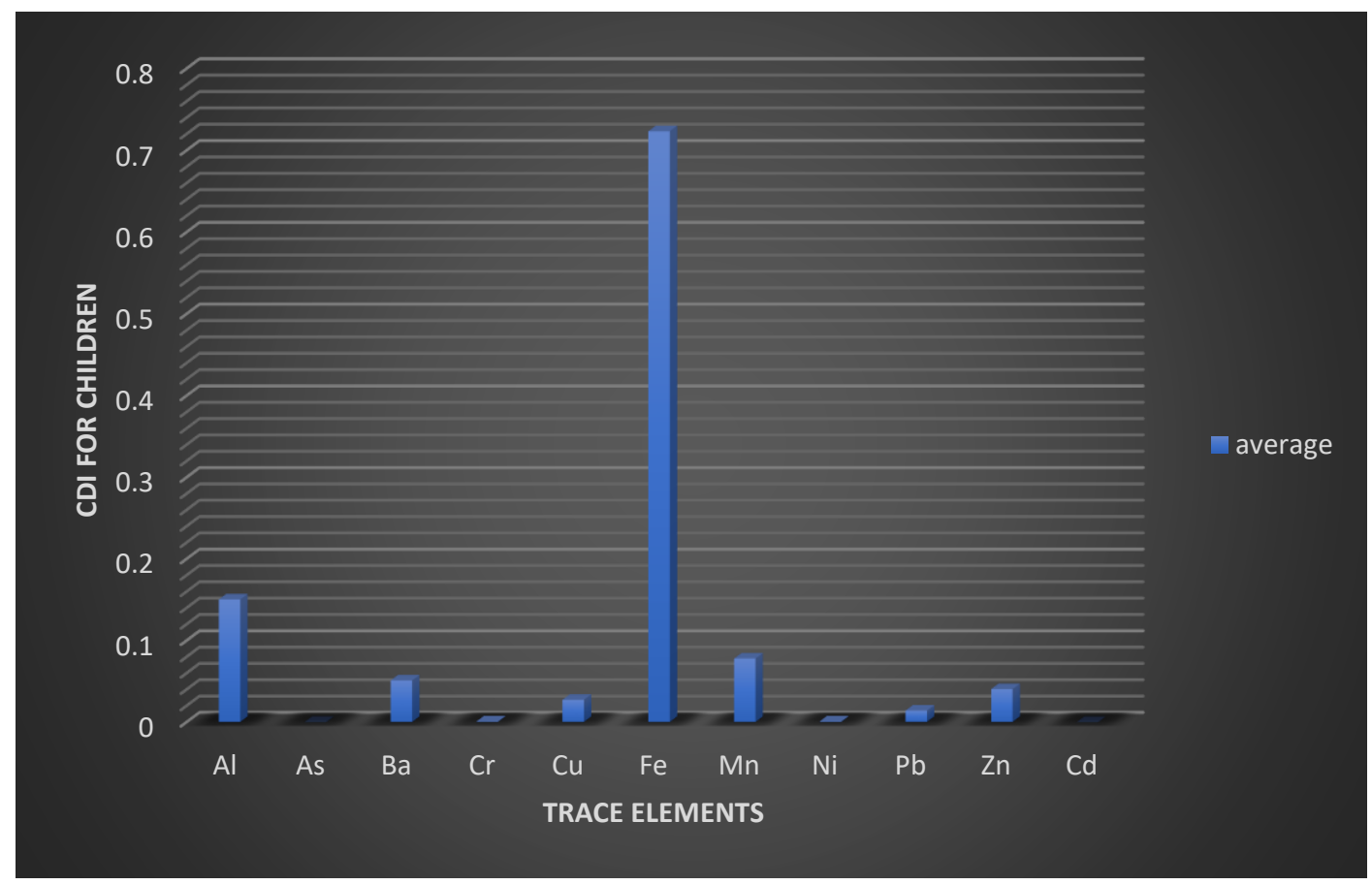

Figure 8: Profile CDI Average Values for Children 
Preliminary Health Risk Assessment in Relation to Some Trace Elements in Ogunpa River, SW Nigeria

Table 8: Statistical Summary of Chronic Daily Intake for Adults

Chronic Daily Intake (CDI) for Adults

\begin{tabular}{|c|c|c|c|c|c|c|c|c|c|c|c|}
\hline Sample ID & $\mathrm{Al}$ & As & $\mathrm{Ba}$ & $\mathrm{Cr}$ & $\mathrm{Cu}$ & $\mathrm{Fe}$ & $\mathrm{Mn}$ & $\mathrm{Ni}$ & $\mathrm{Pb}$ & $\mathrm{Zn}$ & $\mathrm{Cd}$ \\
\hline $20 \mathrm{RO} 1$ & 0.109591 & 0.000113143 & 0.04068 & 0.000484 & 0.026928 & 0.41400857 & 0.04975 & 0.000367714 & 0.012448857 & 0.037645 & 8.76857E-05 \\
\hline $20 \mathrm{RO} 2$ & 0.008391 & $5.65714 \mathrm{E}-05$ & 0.004762 & 0.000088 & 0.001138 & 0.0385 & 0.00994 & 0.000125714 & 0.000348857 & 0.001257 & 5.02857E-06 \\
\hline $20 \mathrm{RO} 3$ & 0.095323 & 0.000116286 & 0.020193 & 0.000477714 & 0.014133 & 0.55854857 & 0.024197 & 0.000553143 & 0.008837714 & 0.021233 & 0.000131686 \\
\hline $20 \mathrm{RO} 4$ & 0.007134 & $5.65714 \mathrm{E}-05$ & 0.005116 & $9.42857 \mathrm{E}-05$ & 0.00028 & 0.04601143 & 0.011686 & 0.000119429 & 0.000223143 & 0.000905 & $3.14286 \mathrm{E}-06$ \\
\hline $20 \mathrm{RO} 5$ & 0.008611 & 4.71429E-05 & 0.004818 & 0.000088 & 0.000198 & 0.03916 & 0.014422 & 0.000103714 & 0.000103714 & 0.000471 & $1.88571 \mathrm{E}-06$ \\
\hline 20 RO6 & 0.00726 & $5.34286 \mathrm{E}-05$ & 0.004705 & 0.000116286 & 0.000321 & 0.04035429 & 0.012407 & 0.000119429 & 0.000232571 & 0.001964 & $2.82857 \mathrm{E}-06$ \\
\hline average & 0.039385 & $7.38571 \mathrm{E}-05$ & 0.013379 & 0.000224714 & 0.007166 & 0.18943048 & 0.0204 & 0.000231524 & 0.003699143 & 0.010579 & $3.87095 \mathrm{E}-05$ \\
\hline $\min$ & 0.007134 & 4.71429E-05 & 0.004705 & 0.000088 & 0.000198 & 0.0385 & 0.00994 & 0.000103714 & 0.000103714 & 0.000471 & $1.88571 \mathrm{E}-06$ \\
\hline $\max$ & 0.109591 & 0.000116286 & 0.04068 & 0.000484 & 0.026928 & 0.55854857 & 0.04975 & 0.000553143 & 0.012448857 & 0.037645 & 0.000131686 \\
\hline stdev & 0.049067 & $3.185 \mathrm{E}-05$ & 0.014716 & 0.00019869 & 0.01112 & 0.23445147 & 0.015237 & 0.000186895 & 0.005499339 & 0.015511 & 5.67205E-05 \\
\hline var & 0.002408 & $1.01442 \mathrm{E}-09$ & 0.000217 & 3.94776E-08 & 0.000124 & 0.05496749 & 0.000232 & 3.49297E-08 & $3.02427 \mathrm{E}-05$ & 0.000241 & $3.21721 \mathrm{E}-09$ \\
\hline med & 0.008501 & $5.65714 \mathrm{E}-05$ & 0.004967 & 0.000105286 & 0.000729 & 0.04318286 & 0.013414 & 0.000122571 & 0.000290714 & 0.001611 & $4.08571 \mathrm{E}-06$ \\
\hline
\end{tabular}


Table 9: Statistical Summary of Chronic Daily Intake for Children

\begin{tabular}{lllllllllllll}
\hline \multicolumn{10}{c}{ Chronic Daily Intake for children (CDI) } \\
& $\mathrm{Al}$ & $\mathrm{As}$ & $\mathrm{Ba}$ & $\mathrm{Cr}$ & $\mathrm{Cu}$ & $\mathrm{Fe}$ & $\mathrm{Mn}$ & $\mathrm{Ni}$ & $\mathrm{Pb}$ & $\mathrm{Zn}$ & $\mathrm{Cd}$ \\
\hline \hline 20 RO1 & 0.418440 & 0.000432 & 0.155324 & 0.001848 & 0.102816 & 1.580760 & 0.189955 & 0.001404 & 0.047532 & 0.143736 & 0.000335 \\
20 RO2 & 0.032040 & 0.000216 & 0.018182 & 0.000336 & 0.004344 & 0.147000 & 0.037952 & 0.000480 & 0.001332 & 0.004800 & 0.000019 \\
20 RO3 & 0.363960 & 0.000444 & 0.077102 & 0.001824 & 0.053964 & 2.132640 & 0.092387 & 0.002112 & 0.033744 & 0.081072 & 0.000503 \\
20 RO4 & 0.027240 & 0.000216 & 0.019532 & 0.000360 & 0.001068 & 0.175680 & 0.044618 & 0.000456 & 0.000852 & 0.003456 & 0.000012 \\
20 RO5 & 0.032880 & 0.000180 & 0.018395 & 0.000336 & 0.000756 & 0.149520 & 0.055064 & 0.000396 & 0.000396 & 0.001800 & 0.000007 \\
20 RO6 & 0.027720 & 0.000204 & 0.017963 & 0.000444 & 0.001224 & 0.154080 & 0.047371 & 0.000456 & 0.000888 & 0.007500 & 0.000011 \\
\hline \multirow{2}{*}{ average } & 0.150380 & 0.000282 & 0.051083 & 0.000858 & 0.027362 & 0.723280 & 0.077891 & 0.000884 & 0.014124 & 0.040394 & 0.000148 \\
\hline \hline min & 0.027240 & 0.000180 & 0.017963 & 0.000336 & 0.000756 & 0.147000 & 0.037952 & 0.000396 & 0.000396 & 0.001800 & 0.000007 \\
max & 0.418440 & 0.000444 & 0.155324 & 0.001848 & 0.102816 & 2.132640 & 0.189955 & 0.002112 & 0.047532 & 0.143736 & 0.000503 \\
stdev & 0.187346 & 0.000122 & 0.056190 & 0.000759 & 0.042458 & 0.895178 & 0.058178 & 0.000714 & 0.020997 & 0.059224 & 0.000217 \\
var & 0.035098 & 0.000000 & 0.003157 & 0.000001 & 0.001803 & 0.801344 & 0.003385 & 0.000001 & 0.000441 & 0.003507 & 0.000000 \\
med & 0.032460 & 0.000216 & 0.018964 & 0.000402 & 0.002784 & 0.164880 & 0.051218 & 0.000468 & 0.001110 & 0.006150 & 0.000016 \\
\hline \hline
\end{tabular}

Carcinogenic Risk Assessment (CRing): Carcinogenic risk assessment, defined as the incremental probability that a consumer will develop cancer during his or her lifetime as a result of exposure, was calculated for both adult and children. Table 10 presents the calculated CRing for Ogunpa river water and Figures 10 and 11 present the carcinogenic profiles. The average values of $\mathrm{Cr}, \mathrm{Cd}$ and $\mathrm{Pb}$ for adults are: $0.00054,7.63 \mathrm{E}-06$ and 0.523 respectively. The average value computed for $\mathrm{Cr}$ and $\mathrm{Pb}$ are higher than $10^{-6}$, which is an indication that the water could pose serious health issue to an individual consuming the water. The average values computed for children are: $0.0017,2.422 \mathrm{E}-05$ and 1.66 respectively. All the values computed for children are higher than the recommended limits of $10^{-6}$ which could pose serious carcinogenic health problems for children. The profiles of Carcinogenic Risk for Adults and Children are presented in Figures 9 and 10.

Table 10: Carcinogenic Risk Assessment ( $\mathrm{CR}_{\text {ing }}$ ) of $\mathrm{Cr}, \mathrm{Cd}$ and $\mathrm{Pb}$ for Adults and Children Carcinogenic risk (CRing) for adults Carcinogenic Risk (CRing) for children

\begin{tabular}{llrrrrr} 
Sample ID & $\mathrm{Cr}$ & $\mathrm{Cd}$ & $\mathrm{Pb}$ & $\mathrm{Cr}$ & $\mathrm{Cd}$ & $\mathrm{Pb}$ \\
\hline \hline 20 RO1 & 0.001163556 & $1.72787 \mathrm{E}-05$ & 1.7604444 & 0.003696 & $5.48852 \mathrm{E}-05$ & 5.592 \\
$20 \mathrm{RO} 2$ & 0.000211556 & $9.90893 \mathrm{E}-07$ & 0.0493333 & 0.000672 & $3.14754 \mathrm{E}-06$ & 0.156705882 \\
$20 \mathrm{RO3}$ & 0.001148444 & $2.5949 \mathrm{E}-05$ & 1.2497778 & 0.003648 & $8.24262 \mathrm{E}-05$ & 3.969882353 \\
20 RO4 & 0.000226667 & $6.19308 \mathrm{E}-07$ & 0.0315556 & 0.00072 & $1.96721 \mathrm{E}-06$ & 0.100235294 \\
20 RO5 & 0.000211556 & $3.71585 \mathrm{E}-07$ & 0.0146667 & 0.000672 & $1.18033 \mathrm{E}-06$ & 0.046588235 \\
20 RO6 & 0.000279556 & $5.57377 \mathrm{E}-07$ & 0.0328889 & 0.000888 & $1.77049 \mathrm{E}-06$ & 0.104470588 \\
\hline average & 0.000540222 & $7.62781 \mathrm{E}-06$ & 0.5231111 & 0.001716 & $2.42295 \mathrm{E}-05$ & 1.661647059 \\
min & 0.000211556 & $3.71585 \mathrm{E}-07$ & 0.0146667 & 0.000672 & $1.18033 \mathrm{E}-06$ & 0.046588235 \\
max & 0.001163556 & $2.5949 \mathrm{E}-05$ & 1.7604444 & 0.003696 & $8.24262 \mathrm{E}-05$ & 5.592 \\
stdev & 0.000477658 & $1.11769 \mathrm{E}-05$ & 0.7776843 & 0.00151727 & $3.55031 \mathrm{E}-05$ & 2.470291182 \\
var & $2.28157 \mathrm{E}-07$ & $1.24923 \mathrm{E}-10$ & 0.6047928 & $2.3021 \mathrm{E}-06$ & $1.26047 \mathrm{E}-09$ & 6.102338525 \\
med & 0.000253111 & $8.051 \mathrm{E}-07$ & 0.0411111 & 0.000804 & $2.55738 \mathrm{E}-06$ & 0.130588235 \\
\hline \hline
\end{tabular}




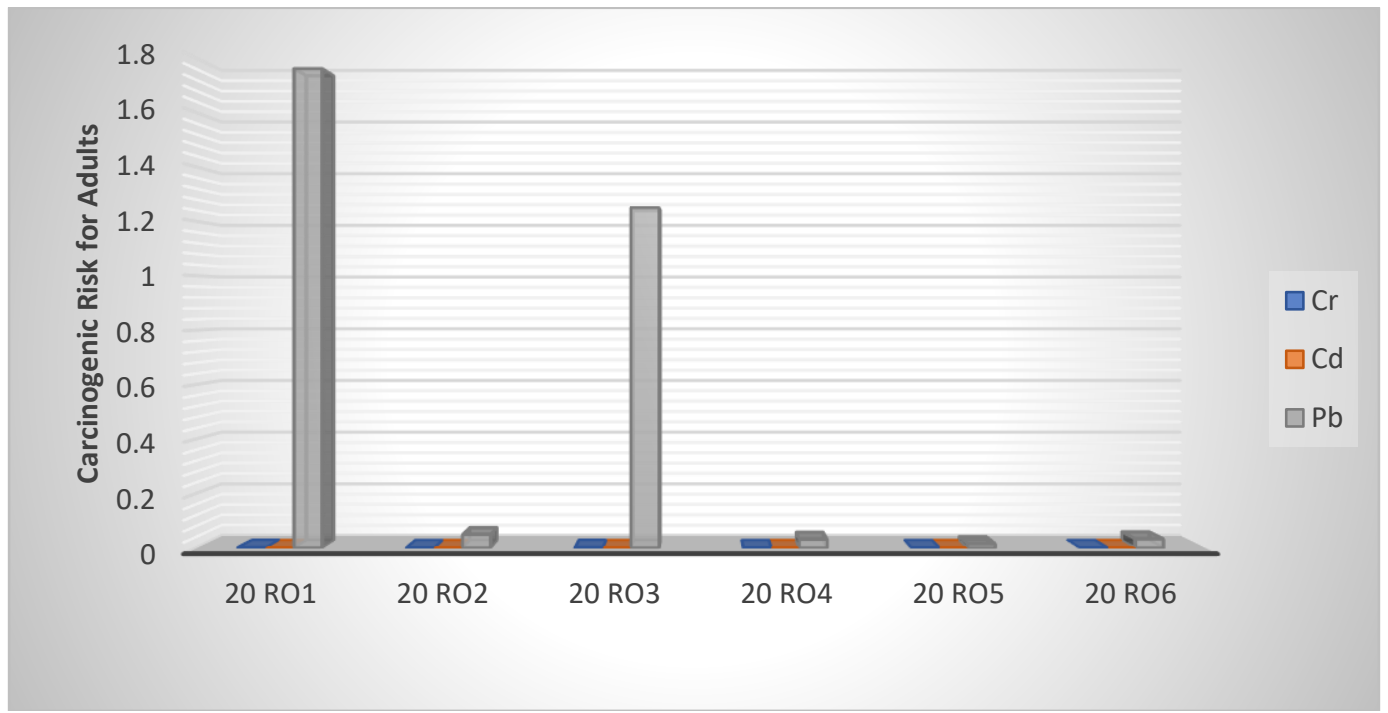

Figure 9: Profile of the Carcinogenic Risk for Adults

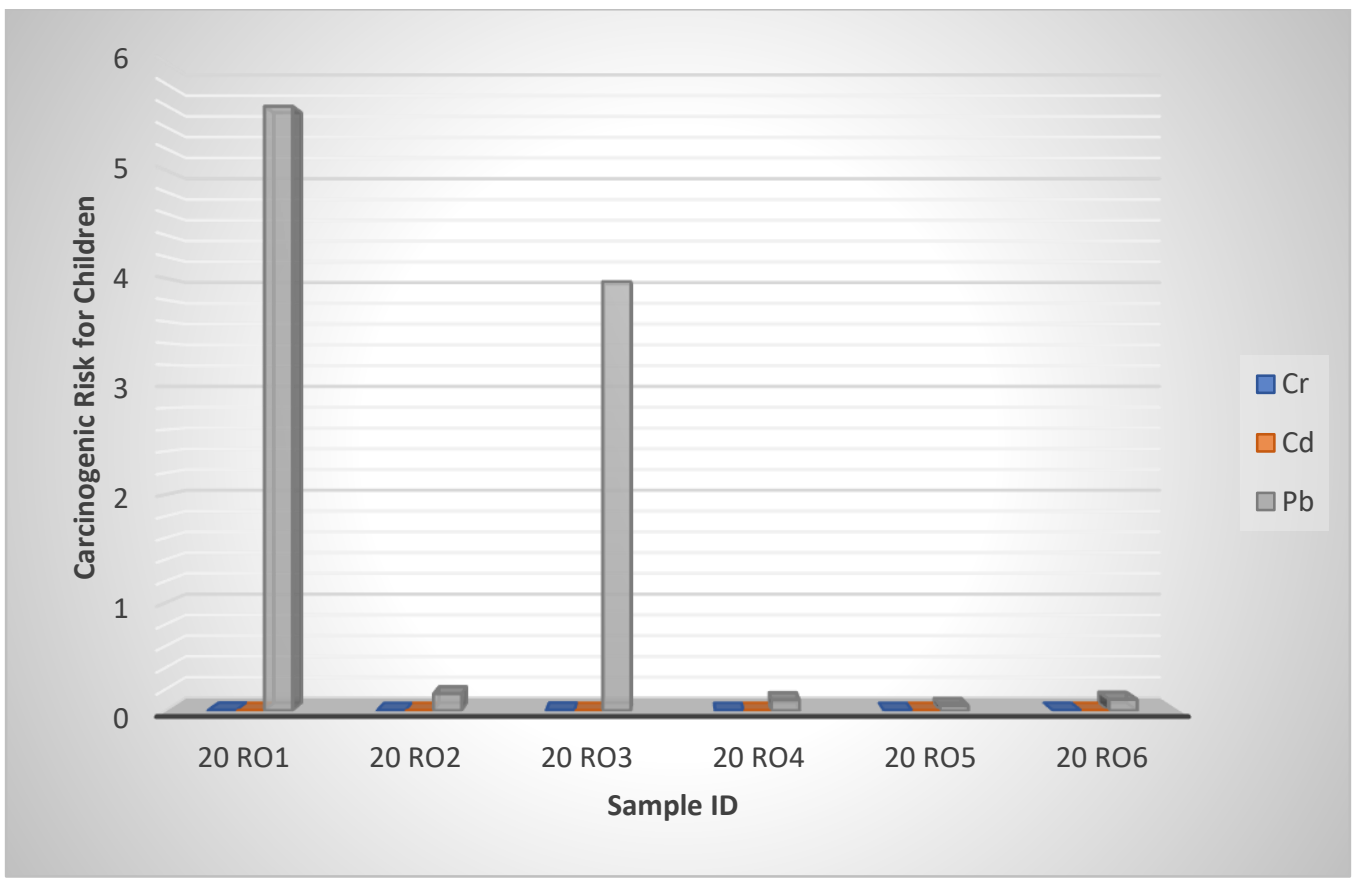

Figure 10: Profile of the Carcinogenic Risk for Children

\section{Conclusion}

This study examines the health risk that indiscriminate dumping and discharging of municipal and industrial wastes into Ogunpa River could pose to the consumers. This was carried out empirically using computed contamination Indexes, Average Daily Dose, Hazard Quotient, Hazard Index, Chronic Daily Intake and Carcinogenic Risk. It was concluded based on the results that the water could pose various life-threatening diseases in Adults and Children consumers. Hence, effort should be made to checkmate indiscriminate dumping of refuse and sewages into the body of the water system. 
LAUTECH Journal of Civil and Environmental Studies

Volume 6, Issue 1; March 2021

\section{Acknowledgement}

The authors wish to acknowledge ACME laboratory, Vancouver, Canada, North America for carrying out the detailed hydrochemical analyses of the water samples.

\section{References}

Asare-Donkor, N. K., Boadu, T. A. and Adimado, A. A. (2016) Evaluation of groundwater and surface water quality and human risk assessment for trace metals in human settlements around the Bosomtwe Crater Lake in Ghana. SpringerPlus 5(1):1812 (PubMed PMID: PMC5069212).

Atiemo, M. S., Ofosu, G. F., Mensah, H. K., Tutu, A. O., Linda-Palm, N.D.M. and Blankson, S. A.

(2011) Contamination Assessment of Heavy Metals in Road Dust from Selected Roads in Accra, Ghana. Research Journal of Environmental and Earth Sciences 3(5): 473-480.

Chang, S. X., Gu, B. and Ge, Y. (2013) Nitrate in groundwater of China: Sources and driving forces[J]. Global Environmental Change, 23(5):1112-1121.

DWAF, (1996) South African water quality guidelines, vol 1, 2nd edn. Domestic Water Use Department of Water Affairs and Forestry Pretoria, Pretoria.

Edokpayi, J.N., Enitan, A.M., Mutileni, N. and Odiyo, J. O. (2018) Evaluation of water quality and human risk assessment due to heavy metals in groundwater around Muledane area of Vhembe District, Limpopo Province, South Africa. Chemistry Central Journal 12, 2 (2018).

https://doi.org/10.1186/s13065-017-0369-y.

Ekere, N. R., Ihedioha, J. N., Eze, I. S. and Agbazue, V. E. (2014) Health risk assessment in relation to heavy metals in water sources in rural regions of south east Nigeria. vol.9(6). pp. 109-116.

Giandomenico, S., Cardellicchio, N., Spada, L., Annicchiarico, C., and Di, L. A. (2016) Metals and PCB levels in some edible marine organisms from the Ionian Sea: dietary intake evaluation and risk for consumers. Environ Sci Pollut Res 23(13):12596-12612.

Han, X. (2011) Urban water quality risk assessment and emergency treatment methods [D]. Xi'an University of Architecture and Technology.

Iqbal, J. and Shah, M. H. (2013) Health risk assessment of metals in surface water from freshwater source lakes Pakistan. Hum Ecol Risk Assess Inter. J. 19(6):1530-1543.

Joel, E. S., Maxwell, O., Adewoyin, O. O., Ehi-Eromosele,C. O., Embong, Z. and Oyawoye, F. (2018) Assessment of natural radioactivity in various commercial tiles used for building purposes in Nigeria. MethodsX, 5, 8-19. doi: 10.1016/j.mex.2017.12.002.

Jones, H. A., and Hockey, R. D. (1964) The Geology of part of Southwestern,Nigeria. Geol Surv of Nigeria Bull 31: 101.

Kavcar, P., Sofuoglu, A., Sofuoglu, S.C. (2009) A health risk assessment for exposure to trace metals via drinking water ingestion pathway. Environ. Health 212, 216-227.

Khadam, I.K., Kaluarachchi, J.J. (2003) Multi-criteria decision analysis with probabilistic risk assessment for the management of contaminated groundwater. Environ. Impact Assess. Rev. 23, 683-721.

Li SY, and Zhang, Q. F. (2010) Spatial characterization of dissolved trace elements and heavy metals in the upper Han River (China) using multivariate statistical techniques. $J$ Hazard Mater 176(1-3):579. 
Li, W., Tian, M., Ruan, M., Wei, J. and Ma, W. (2019) Water quality pollutants and health risk assessment for four different drinking water sources. E3S Web of conferences 78, 03004.

Maxwell, O., Adewoyin, O. O., Joel, E. S. and Ehi-Eromosele, C. O. (2018) Radiation exposure to dwellers due to naturally occurring radionuclides found in selected commercial building materials sold in Nigeria. Journal of Radiation Research and Applied Sciences, (in press) 11, 225-231. doi:10.1016/j. jrras.2018.01.007.

Naveedullah, M. Z. H., Yu, C., Shen, H., Duan, D. and Shen, C. (2014) Concentration and human health risk assessment of selected heavy metals in surface water of the siling reservoir watershed in Zhejiang Province, China. Pol J Environ Stud 23(3):801-811.

NSDWQ, (2007) Nigerian standard for drinking water quality. Standard organization of Nigeria. http://www.unicef.org/nigeria/ng_publications_Nigerian_standard_for_drinking_water_q uality.pdf.

Oladunjoye, M. A., Akanji, A. O. and Akingbesote, O. T. (2013) Groundwater Exploration in Alakuta-Awotan area of Ibadan, Southwestern Nigeria. J Geol Geosci 2013, 2:3 DOI: 10.4172/2329-6755.1000124.

Olujimi, O. O., Oputu O, Fatoki, O., Opatoyinbo, O. E., Aroyewun, O.A. and Baruani, J. (2015) Heavy metals speciation and human health risk assessment at an illegal gold mining site in Igun, Osun State, Nigeria. J Health Pollut 5(8):19-32.

Sudsandee, S., Tantrakarnapa, K., Tharnpoophasiam, P., Limpanont, Y., Mingkhwan, R. and

Worakhunpiset, S. (2017) Evaluating health risks posed by heavy metals to humans consuming blood cockles (Anadara granosa) from the Upper Gulf of Thailand. Environ Sci Pollut Res 24(17):14605-14615

Tijani, M.N., Okunlola, O.A. and Ikpe, E.U. (2007) A geochemical assessment of water and bottom sediments contamination of Eleyele Lake catchment, Ibadan, Southwestern Nigeria.

19(1): 105-120.

USEPA, (2001) Baseline human health risk assessment, Vasquez Boulevard and I-70 Superfund site.Denver,CO: U.S. Public Health Service.http://www.epa.gov/region8/ superfund/sites/VB-170-Risk.pdf.

USEPA, (1989) Risk assessment guidance for superfund, vol 1, human health evaluation manual (part A), Report EPA/540/1-89/002, United States Environmental Protection Agency, Washington, DC.

Viers, J., Dupre, B. and Gaillardet, J. (2009) Chemical composition of suspended sediments in World River: New insights from a new data base. Science of the Total Environment. 407(2):853-868. www.elsevier.com/locate/scitotenv.

World Health Organization, (1995) Lead. Environmental health criteria. 165. Geneva. World health organization.

World Health Organization, (2006) Guidelines for drinking-water quality, addendum to volume 1: recommendations, 3rd edn. World Health Organization, Geneva.

Yuan, Y., Xiang, M., Liu, C., and Theng, B. K. G. (2017) Geochemical characteristics of heavy metal contamination induced by a sudden wastewater dis-charge from a smelter. Journal of Geochemical Exploration, 176,33-41. doi:10.1016/j. gexplo.2016.07.00 